\title{
Modern approaches of detecting financial statement fraud
}

\author{
Liudmila Tkachenko*, Erisov Andrey, Galina Pozdeeva, Vera Romanyuk \\ Institute of Natural Resources, National Research Tomsk State University, 36 Lenin Av., Tomsk, \\ 634050, Russia
}

\begin{abstract}
The paper considers the modern methods for detecting financial statement errors and fraud with respect to their application to Russian corporate companies. The study methods evaluating the financial statements of companies allow getting a comprehensive and quick assessment of the financial condition of the company based on open sources. An assessment of the financial statements of enterprises according to the Roxas model showed that the composite index of the model is applicable to Russian companies.
\end{abstract}

\section{Introduction}

Typically, when studying the financial condition of the counterparty, there is no access to the organization's management accounting. Due to the major changes in the financial condition of a considerable number of corporate companies, it is necessary to strengthen control over the financial indicators changes of the counterparties for economic security purposes.

Financial condition assessment helps obtaining data on the actual size of the company's reserves and its ability to service the obligations assumed. It also can serve as a source of information on errors made in accounting and keeping records as well as indicate the possible cases of fraud. In addition, the organization's security services need operational information to evaluate a large number of contractual counterparties.

The confidential management accounting and available economic information only to a restricted number of people within the enterprise force external users to apply modern approaches for evaluating open data.

For instance, top managers of the company or other officials may misrepresent the financial statements to demonstrate to the company's owners or shareholders the state of affairs in a more favorable light in order to enrich themselves, conduct unauthorized transactions, or unwittingly make errors in accounting due to insufficient competence of responsible persons.

\section{Materials and methods}

${ }^{*}$ Corresponding author: ludmila.i.tkachenko@gmail.com 
Fraud is intentional actions resulting in material misstatement of the company's financial statements. These actions are taken by management or employees responsible for keeping records at the company in order to obtain unjustified economic benefits or advantages.

In turn, an error is an incorrect reflection or non-reflection of the facts of economic activity in accounting and (or) accounting statements of the organization. For instance, an error may be caused by incorrect application of the legislation of the Russian Federation legislation on accounting or regulations, incorrect application of the organization's accounting policies, or misclassification of business operations.

An attempt to compensate the intentional financial misstatements in subsequent periods will lead to unfounded final indicators changes relative to previous ones. This will result in either new facts of misstatement, or recognition of such actions in the past. The misstatement objects are:

- key reporting indicators (revenue, profit, assets, etc.);

- data generation and processing system (including primary data);

- operating environment and internal control system.

Interference in the second and third groups of misstatement objects leads to systematic misrepresentation of accounting, the identification of which will require a deeper analysis of the state of affairs of the enterprise. Additional assessment of internal business operations indirectly indicating the possible fraud may serve as prerequisites for its implementation:

- non-compliance of current capital value with the growth of sales or profit;

- the company's dependence on a single supplier or customer;

- non-typical transactions especially in the run up of the end of the reporting period;

- availability of payments for services that do not correspond to the cost or volume, etc.

The results of the world economic crime survey for 2018, prepared by $\mathrm{PwC}$, indicate that in our country, the most popular type of corporate fraud is misappropriation of assets. In total, $49 \%$ of respondents claimed that their companies faced economic crimes, compared to those $36 \%$ in 2016 . The increase in this indicator may be due not only to an increase in the number of crimes, but also to an increase in their detection efficiency. It should also be taken into account that many companies claimed that they have not encountered such issues may basically not know about them, since their identification requires significant costs of the enterprise. About $15 \%$ of managers noted that their companies spent an amount equal to the damage incurred on investigations and detection of economic crimes. About 22\% managers said that this amount is 2-10 times higher than the amount of damage. Thus, the costs for detecting such facts are indirect damage from economic crimes at enterprises [1].

This is only a measurable amount of damage. It is also worth considering non-monetary consequences: the reputation of the company or the entire industry which leads to a decrease in investment attractiveness, an increase in transaction costs and a decrease in economic activity in general. It is also worth noting the negative impact of such actions and their damage on the organization's staff morale and relations between market participants.

Thus, the application of modern tools for detecting fraud is a necessary and integral part of the current activities of the company's financial control service.

To assess the quality of financial statements, the model developed by American professor Messod D. Beneish should be considered. Currently, this method of fraud detecting has shown high accuracy. Fraud detection percentage of the method accounts for 89.5\%). [2].

These models are based on regression and discriminant analysis methods. Beneish adopted the following basic model as a basis:

$$
M_{i}=\beta^{\prime} X_{i}+\tilde{\varepsilon}
$$


where $\mathrm{M}_{i}$ is a dichotomous variable taking the value 1 for companies frauding on accounts;

$\mathrm{X}_{i}$ is a vector of explicative variables;

$\tilde{\varepsilon}$ is a vector of errors.

In his research, M. Beneish evaluated 2.400 American companies and found a relationship between the probability of financial statement fraud and a number of financial indicators of the enterprise.

The result of the investigation was the composite index of the risk valuation of financial statement fraud - M-score:

$$
\begin{gathered}
M-\text { score }=-4.84+0.920 \times D S R I+0.528 \times G M I+0.404 \times A Q I+0.892 \times S G I+0.115 \times \\
D E P I-0.172 \times S G A I+4.679 \times T A T A-0.327 \times L V G I
\end{gathered}
$$

where: DSRI is Days Sales in Receivables Index;

GMI is Gross Margin Index;

AQI is Asset Quality Index;

SGI is Sales Growth Index;

DEPI is Depreciation Index;

SGAI is Sales General and Administrative Expenses Index;

LVGI is Leverage Index;

TATA is Total Accruals to Total Assets.

Investigating the financial statements data of companies from the United States, Beneish determined the boundaries of the financial indicators used in the model, exceeding which increases the probability of misrepresentation of the presented financial statements. Based on them, the threshold value of the M-score composite index was determined for organizations that did not perform creative accounting with 2.2.

the value of $\mathrm{M}$-score $\leq-2.2$ - the presence of misstatement is unlikely;

M-score value $\geq-2.2$ - possible misstatement.

The Beneish model was tested and verified by Maria L. Roxas in 2011, using the example of American companies as well [3].

After analyzing the indicators used by Beneish, Roxas declined to include Sales General and Administrative Expenses Index (SGAI), Leverage Index (LVGI), and Total Accruals to Total Assets (TATA) as having an insignificant impact. As a result, we get a new term of the $\mathrm{m}$-score indicator, limited to five indicators and recalculated thresholds:

$$
\begin{gathered}
M-\text { score }=-6.065+0.823 \times D S R I+0.906 \times G M I+0.593 \times A Q I+0.717 \times \\
S G I+0.107 \times D E P I
\end{gathered}
$$

Roxas also recalculated the threshold value of the m-score composite index for organizations that did not perform creative accounting, which was 2.76.

- M-score value $\leq-2.76-$ misstatement is unlikely;

- the value of M-score $\geq-2.76$ - possible presence of misstatements.

Thus, the Beneish and Roxas models are efficient modern tools for detecting misrepresentations in companies' financial statements. However, they are based on the data of companies represented in the US market, and are only valid for similar businesses due to differences in the methods of accounting and reporting.

The applicability of Beneish and Roxas models for detecting fraud statements in companies keeping records in accordance with Russian accounting standards was studied by N. V. Feruleva and M. A. Stefan [4]. The M-score composite index developed by Beneish 
was upgraded by excluding Depreciation Indexes (DEPI) and Total Accruals to Total Assets (TATA), and boundary values were set to adapt the model to Russian conditions (Table 1).

Table 1. Boundary values of financial indicators [4]

\begin{tabular}{|c|c|c|c|c|c|c|}
\hline \multirow{2}{*}{ Value } & \multicolumn{7}{|c|}{ Indicator } \\
\cline { 2 - 7 } & DSRI & GMI & AQI & SGI & SGAI & LVGI \\
\hline $\begin{array}{c}\text { According to Russian } \\
\text { companies }\end{array}$ & 1.408 & 1.260 & 1.186 & 1.280 & 1.025 & 1.119 \\
\hline $\begin{array}{c}\text { According to the American } \\
\text { companies }\end{array}$ & 1.031 & 1.014 & 1.039 & 1.134 & 1.000 & 1.000 \\
\hline
\end{tabular}

Taking into account the changed boundary values of financial indicators for Russian companies, the thresholds of the composite index were also recalculated:

- M-score Beneish - -1.802;

- M-score Roxas - -2.146.

Based on these models, the authors of the study evaluated the reporting on the probability of its distortion of leading Russian companies from various sectors of the economy. In Table 2 the results of calculating the M-score composite index are presented [7].

Table 2. Composite index (Beneish model) for Russian companies [7]

\begin{tabular}{|c|c|c|c|c|}
\hline \multirow{2}{*}{ Company } & \multicolumn{4}{|c|}{ M-score (Beneish model) } \\
\cline { 2 - 5 } & 2015 & 2016 & 2017 & 2018 \\
\hline A & -1.8579 & -2.6027 & -4.1043 & -1.6399 \\
\hline B & -2.6781 & -1.8862 & -1.9219 & -2.0380 \\
\hline C & -2.1484 & -2.2590 & -2.7102 & -3.0619 \\
\hline D & -6.0849 & -2.0720 & -1.4921 & -1.3889 \\
\hline E & -2.6143 & $-2,1564$ & -2.2925 & -2.4237 \\
\hline F & -3.1723 & -2.0926 & -1.9062 & -2.6539 \\
\hline G & -2.6530 & -2.5954 & -2.1708 & -2.2314 \\
\hline
\end{tabular}

\section{M-SCORE}

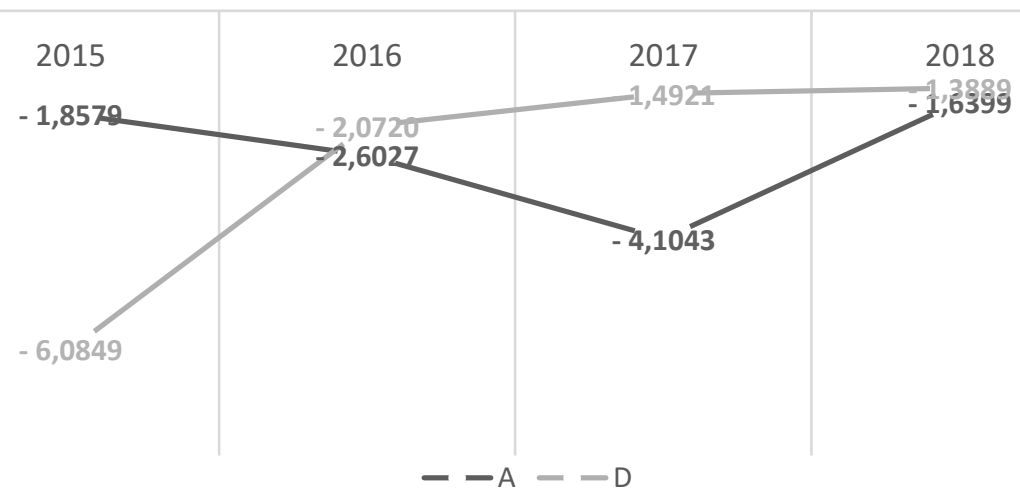

Fig. 1. Diagram of changes in M-score indicators (Beneish model) 
When analyzing the results (Table 2), it can be seen that only two companies exceed the threshold value of the composite index: A and D.

For company A (Table 3), these changes in 2018 are due to a sharp decrease in the company's revenue for 2017 by 52\% compared to this indicator in 2016. In the 2018 report, the company again showed revenue growth of $85 \%$ from the 2016 level. Excluding this factor, the dynamics of the company's indicators shows a steady decrease in the relative threshold value (Figure 1).

In turn, company D 2017-2018 was in an active investment phase, raising funds, as a result of which the company's accounts receivable and balance sheet increased by more than $30 \%$ in 2018 , which affected the daily sales indices in accounts receivable and asset quality (Table 4).

Table 3. Coefficient values of A company for the Beneish model [7]

\begin{tabular}{|c|l|c|c|c|c|c|}
\hline \multicolumn{2}{|c|}{ Name of the indicator } & Symbol & $\mathbf{2 0 1 5}$ & $\mathbf{2 0 1 6}$ & $\mathbf{2 0 1 7}$ & $\mathbf{2 0 1 8}$ \\
\hline 1 & Days Sales in Receipts Index & DSRI & 2.5216 & 0.9968 & 0.9392 & 0.7329 \\
\hline 2 & Gross Margin Index & GMI & 0.8614 & 1.0136 & 0.9582 & 1.1191 \\
\hline 3 & Asset Quality Index & AQI & 0.9035 & 1.1648 & 0.9977 & 0.9764 \\
\hline 4 & Sales Growth Index & SGI & 0.5179 & 1.1888 & 0.5208 & 1.6335 \\
\hline 5 & Depreciation Index & DEPI & 0.7034 & 0.9729 & 0.9364 & 1.0116 \\
\hline 6 & $\begin{array}{l}\text { Sales General and Administrative } \\
\text { Expenses Index }\end{array}$ & SGAI & 2.2638 & 0.9460 & 1.1834 & 0.6058 \\
\hline 7 & Leverage Index & LVGI & 1.3124 & 1.2194 & 1.4585 & 1.1214 \\
\hline 8 & Total Accruals to Total Assets & TATA & 0.0252 & -0.0633 & -0.1986 & 0.0936 \\
\hline 9 & M-score (Beneish model) & & -1.8579 & -2.6027 & -4.1043 & -1.6399 \\
\hline 10 & M-score (Roxas model) & & -2.2270 & -2.6792 & -3.3587 & -2.5894 \\
\hline
\end{tabular}

Table 4. Coefficient values of D company for the Beneish model [7]

\begin{tabular}{|c|l|c|c|c|c|c|}
\hline \multicolumn{2}{|c|}{ Name of the indicator } & Symbol & $\mathbf{2 0 1 5}$ & $\mathbf{2 0 1 6}$ & $\mathbf{2 0 1 7}$ & $\mathbf{2 0 1 8}$ \\
\hline 1 & Days Sales in Receipts Index & DSRI & 1.6489 & 0.8888 & 0.6041 & 1.5437 \\
\hline 2 & Gross Margin Index & GMI & 1.0006 & 1.0193 & 0.9918 & 1.0056 \\
\hline 3 & Asset Quality Index & AQI & -2.7461 & 0.1170 & 0.9031 & 0.6473 \\
\hline 4 & Sales Growth Index & SGI & 1.3677 & 1.3623 & 1.1908 & 1.1408 \\
\hline 5 & Depreciation Index & DEPI & 1.1784 & 0.5827 & 0.8122 & 1.1469 \\
\hline 6 & $\begin{array}{l}\text { Sales General and Administrative } \\
\text { Expenses Index }\end{array}$ & SGAI & 0.9320 & 0.8914 & 1.0172 & 0.9672 \\
\hline 7 & Leverage Index & LVGI & 1.0708 & 1.2186 & 0.8009 & 0.8317 \\
\hline 8 & Total Accruals to Total Assets & TATA & -0.6467 & 0.1356 & 0.2532 & 0.1127 \\
\hline 9 & M-score (Beneish model) & & -6.0849 & -2.0720 & -1.4921 & -1.3889 \\
\hline 10 & M-score (Roxas model) & & -4.3232 & -3.3015 & -3.1930 & -2.5589 \\
\hline
\end{tabular}

Table 5. Composite index (Roxas model) for Russian companies (Compiled by the author in tables 24) 


\begin{tabular}{|c|c|c|c|c|}
\hline \multirow{2}{*}{ Company } & \multicolumn{4}{|c|}{ M-score (Roxas model) } \\
\cline { 2 - 5 } & $\mathbf{2 0 1 5}$ & $\mathbf{2 0 1 6}$ & $\mathbf{2 0 1 7}$ & $\mathbf{2 0 1 8}$ \\
\hline A & -2.2270 & -2.6792 & -3.3587 & -2.5894 \\
\hline B & -2.9457 & -2.6069 & -2.6191 & -2.7156 \\
\hline C & -3.1016 & -2.5269 & -2.1357 & -2.8064 \\
\hline D & -4.3232 & -3.3015 & -3.1930 & -2.5589 \\
\hline E & -2.7981 & -2.7004 & -2.7461 & -2.7968 \\
\hline F & -2.7581 & -2.9144 & -2.9232 & -2.7463 \\
\hline G & -2.7791 & -2.7278 & -2.8507 & -2.8200 \\
\hline
\end{tabular}

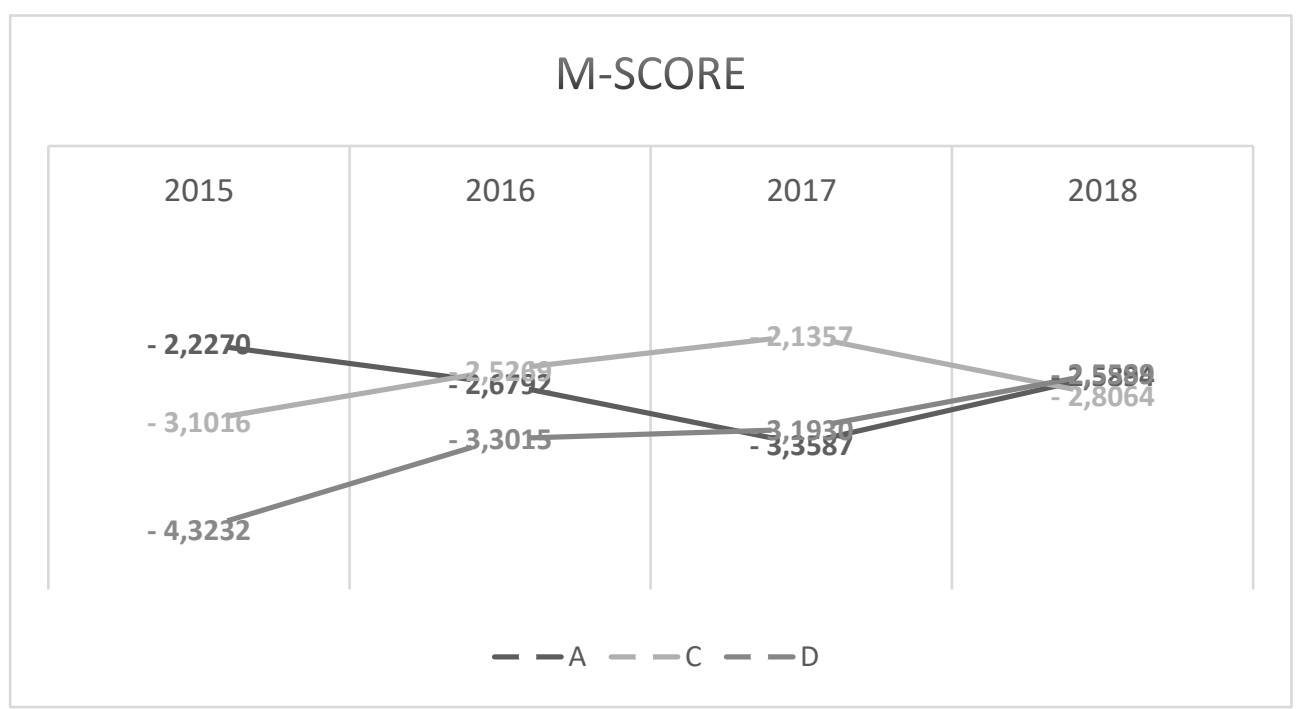

Fig. 2. Diagram of changes in M-score indicators (Roxas model)

Analysis of the financial statements of enterprises by the Roxas model showed that the composite index of the indicator of companies is below the boundary value. The only exception was enterprise C, which slightly exceeded its value in 2017 . The final indicator was also affected, as in the previous example, by a change in the asset quality index caused by a decrease in current assets while increasing non-current assets at the same value of the balance sheet currency.

In turn, companies $\mathrm{A}$ and $\mathrm{D}$, which results exceeded the threshold value when calculating the indicator using the Beneish model, showed the value of the composite index within the acceptable range. It is worth noting that company D's composite index steadily increases over the entire period under review, approaching the boundary value (Figure 2).

The analysis of the applicability of the Beneish and Roxas model for detecting financial statement fraud, taking into account the boundary values calculated for Russian companies by researchers N. V. Feruleva and M. A. Stefan, proved its validity.

A special feature of the study was that these models were used to analyze the accounting of large Russian public joint-stock companies, whose stock indices form the composite indices of MICEX and RTS. Thus, the quality of information provided in their financial documentation directly affects the image of the Russian stock market by investors. 
The accounting of these companies includes a positive audit value, which also confirms the absence of fraud and misstatements proved in this study.

\section{Conclusion}

Due to the peculiarities of accounting, the Roxas model with the boundaries of indicators applicable to Russian companies is more preferable, since it excludes indexes that do not affect the final result, which simplifies the calculation and reduces probable errors.

These methods of evaluating companies' financial statements allow obtaining a comprehensive and rapid assessment of the financial condition of an enterprise based on public sources, but the results of calculations should be used as an additional factor confirming either the probability of misstatements or their absence, and being a prerequisite for additional verification if necessary. To make an unambiguous conclusion about the existence of facts of financial statement fraud, it is necessary to carry out a deeper analysis of the company, external and internal factors that affect changes in indicators, the stage of development of the company, as well as the state of the industry as a whole.

\section{References}

1. Russian economic crime survey 2018. https://www.pwc.ru/ru/forensicservices/assets/PwC-recs-2018-rus.pdf. free, reference date 10.12.2019

2. M. Beneish, The detection of earning manipulation. Financial Analysts Journal, 55(5), 24-36 (1999)

3. M. Roses, Financial statement fraud detection using ratio and digital analysis. Journal of Leadership, Accountability and Ethics, 8(4), 56-66 (2011)

4. N.V. Feruleva, M.A. Stefan, Detection of falsification of financial statements in Russian companies: analysis of the applicability of the Beneish and Roxas models. Russian Management Journal, 14(3), 49-7 (2016)

5. ASFE Report to the nations 2020 - Global study on occupational fraud and abuse. https://acfepublic.s3-us-west-2.amazonaws.com/2020-Report-to-the-Nations.pdf

6. I.V. Safonova, A.D. Silchenko, Falsification of financial statements: concept and tools for identification, Accounting. Analysis. Audit, 5(6), 37-49 (2018)

7. V.B. Romanyuk, A.Yu. Erasov, Modern approaches to detect fraud and error risks in companies' financial statements, Siberian financial school. Accounting, control, and analysis, 5, 102-107 (2019) [in Russian]

8. V. B. Romanyuk et al., Financial planning as a policy tool in the petroleum industry (the case study: ojsc "Surgutneftegas"), IOP Conference Series: Earth and Environmental Science, 43, 012086 (2016) 